\title{
DISASTER MITIGATION ON CULTURAL TOURISM IN LOMBOK, INDONESIA
}

\author{
Neni WAHYUNINGTYAS \\ Universitas Negeri Malang, Faculty of Social Science, Social Studies \\ Program, Malang, Indonesia, e-mail: neni.wahyuningtyas.fis@um.ac.id
}

\author{
Ardyanto TANJUNG \\ Universitas Negeri Malang, Faculty of Social Science, Geography \\ Department, Malang, Indonesia, e-mail: ardyanto.tanjung.fis@um.ac.id \\ Idris IDRIS* \\ Universitas Negeri Malang, Faculty of Social Science, \\ Social Studies program, Malang, Indonesia, e-mail: idris.fis@um.ac.id

\section{Kusuma DEWI} \\ Universitas Negeri Malang, Faculty of Social Science, Geography \\ Department, Malang, Indonesia, e-mail: kusumadewi13579@gmail.com
}

\begin{abstract}
Citation: Wahyuningtyas N., Tanjung A., Idris I. \& Dewi K. (2019). DISASTER MITIGATION ON CULTURAL TOURISM IN LOMBOK, INDONESIA. GeoJournal of Tourism and Geosites, 27(4), 1227-1235. https://doi.org/10.30892/gtg.27409-428
\end{abstract}

\begin{abstract}
The unitary state of the Republic of Indonesia is prone to natural disasters. The loss from natural disasters that occurred was quite large, both in the economic, social and tourism sectors. This requires a company, non-governmental organization (NGO) and the Government to work together to prepare, respond to, and design new effective disaster management strategies. This study aims to determine disaster mitigation efforts and their relationship to cultural tourism areas. Data were collected through literature studies, in-depth interviews, and observations. This study aims to explore disaster mitigation efforts and their links to cultural tourism areas. This research uses a descriptive qualitative approach. Data were collected through literature studies, in-depth interviews, and observations. The study found that disaster mitigation in Segenter Indigenous Village consists of structural and non-structural mitigation. Structural mitigation is based on mechanical mitigation dimensions. Meanwhile, non-structural mitigation includes dimensions of knowledge, values, decision-making mechanisms, and group solidarity. The communities seek disaster mitigation with local knowledge and education or direction from outsiders. The Segenter Indigenous Village community is open to all input as long as it has a positive impact.
\end{abstract}

Key words: disaster mitigation, cultural tourism, local wisdom

\footnotetext{
* Corresponding author
} 


\section{INTRODUCTION}

Indonesia is a country that consists of various ethnic groups with local wisdom and full of potential natural disasters (Asriningpuri, 2018). Natural disasters can include earthquakes, floods, typhoons, volcanic eruptions, and drought (Delita, 2017; Oloruntoba et al., 2018; Orhan, 2016). According to research by the United Nations (UN), Indonesia ranks third as an earthquake-prone country in the world (Isa, 2016).

Report of the Meteorology and Climatology and Geophysics Agency (BMKG), significant and destructive earthquake data that occurred in Indonesia over the past 5 years continued to increase from six times in 2014 to twenty-three times in 2018 (BMKG, 2019).

The disaster caused many losses in various fields such as economic, social, and tourism (Artiani, 2011; Asriningpuri, 2018; Zahnow et al., 2019). Natural disasters often hit Indonesian tourist destinations such as the earthquake in Lombok, West Nusa Tenggara in 2018. The total loss of the Lombok earthquake reached $\mathrm{Rp} 12.15$ trillion. That figure includes building damage of Rp 10.15 trillion and economic losses of Rp 2 trillion (Gumelar, 2018). The successive earthquake of Lombok in 2018 caused 564 fatalities, 1,886 injuries, and 472,419 people were displaced. In addition, it is also known that 4,636 tourists became victims, 100,00o tourists were reduced, and suffered a loss of Rp 1.4 trillion in the tourism sector. Of the many fatalities, the district of North Lombok suffered the highest loss, with 469 dead, 178,122 displaced, and 906 injured (BNPB, 2017). The earthquake in Lombok is a threat to the tourism sector. Tourism is a very macro and dynamic industry.

Many tourists are not only interested in natural beauty, but also turn to tourism products such as religious tourism, the environment, culture, and unique attractions (Permadi et al., 2018). North Lombok is one area in Lombok that has its own tourism charm. North Lombok Regency has beautiful natural charm. This supports the growth of businesses in tourism as a natural tourism destination. On the other hand, cultural tourism is also a tourist destination by local and foreign tourists (BPS Lombok Utara, 2017). One of the cultural tourism is located in Segenter, Sukadana Village, North Lombok. This village is one of the traditional villages in Lombok. The location of the Segenter Indigenous Village, which is close to a small plate, Mount Rinjani, and Gunung Baru, makes this village prone to earthquakes. The risk of disasters in the Segenter Village requires the community to mitigate against disasters. As a concept of developing cultural tourism in the Segenter Indigenous Village community which is thick with its customs is an interesting topic to be studied and analyzed its role in responding to disasters.

Natural disasters require a company, non-governmental organization (NGO), and the Government itself to work together to prepare, respond to, and design new effective disaster management strategies (Oloruntoba et al., 2018). Disaster mitigation is carried out through physical development, rules, and awareness or education. Based on the Regulation of the Head of the National Disaster Management Agency (BNPB) No. 4 of 2008 explained that disaster mitigation is divided into structural mitigation and non-structural mitigation. Structural mitigation is carried out through physical and infrastructure development efforts to reduce disaster risks. Development can also be carried out through technology development (Wulan et al., 2016). Meanwhile, non-structural mitigation is carried out in an awareness or education effort to reduce disaster risk. Managers had to improve for each employee's knowledge about disaster mitigation to be aware of disaster risks and how to overcome them in the company where they work as well as pre-disaster actions to reduce greater risk in Adapazari, Turkey (Orhan, 2016). Disaster managers in Chile utilize the knowledge of local communities, and validate political knowledge as an essential element for efficient disaster management (Tironi \& Manríquez, 2019). Other findings of previous research on disaster mitigation are related to local wisdom. Thene (2016) found that local wisdom is one of the effective ways in disaster mitigation in the people of Rote Ndao. 
Mitigation measures are non-structural mitigation which is proven to be able to minimize the impact of earthquakes that occurred. Suparmini, et al. (2016) explored local wisdom as part of disaster mitigation by the Baduy community. That is in the form of non-structural mitigation such as the worship of Dewi Sri (goddess of rice), the tradition of plantation, the rules of building, and the distribution of forest zones. While structural mitigation consists of; 1) Skills in building houses, bridges, and barns; 2) Conservation of ecosystems with forest zone division; 3) Use of plantation equipment and procedures.

Other forms of disaster structural mitigation also occur in the form of mechanical and vegetative mitigation. Mechanical refers to construction of breakwater, installation of signs for evacuation routes, signs for the indication of return current on the coast, construction of seawalls, and signs for evacuation routes. Vegetative mitigation was carried out by planting mangroves along the coastline. In addition, non-structural mitigation involved early warning system, coast guard, and disaster preparedness community.

This is an effort to mitigate disasters as well as efforts to maintain tourist attraction. Such management makes Pandawa Beach continue to increase in terms of safety and comfort for tourists (Wulan et al., 2016). By highlighting from previous studies, this study takes cultural tourism as one of the objects of disaster mitigation that will be explored various mitigation efforts that have been implemented and pursued.

\section{MATERIALS AND METHODS}

This research used a qualitative descriptive approach in which data are collected in the form of personal documents, interviews, literature studies, and other documents. A qualitative approach seeks to discover and narrate a phenomenon that occurs (Anggito \& Setiawan, 2018; Yusuf, 2017). This study used descriptive data in the form of written or oral words from the observed actors. In-depth exploration of information is revealed to find value, quality, or meaning (Fitrah \& Luthfiyah, 2017). Descriptive research strategies are used to describe, express, or describe various existing data.

Primary data were collected through interviews and observations. The interview is an in-depth interview to get data to reveal the facts. While secondary data was taken from literature study such as documentation (photos), journals, books and various other supporting documents that review about the Segenter Adat Village, North Lombok. This literature was used as supporting data to obtain various information and concepts related to research. Observations and interviews were conducted during May and July 2019 with the community and the Head of Segenter Village.

\section{RESULTS AND DISCUSSIONS}

\section{Disaster Mitigation in Segenter Communities}

Segenter is a village with Sasak people, a native of Lombok. The Sasak people have a traditional house, which is a hereditary building. The building structure of the house is not soaring high and has similarities to the Ancient Bayan Beleq Mosque. The roof has a frame using bamboo and rattan as a binder, the cover uses reeds or grass, the pillars use wood, and the walls are made of woven bamboo. Now it is found that some of the houses in Segenter Village have been turned into permanent buildings.

The earthquake that occurred in Lombok in 2018 caused huge losses, especially in North Lombok. However, this has a different impact on cultural tourism in Segenter. The total number of permanent residential buildings in Segenter that were damaged by the earthquake was slight. The majority of the conditions of the post-earthquake Segenter Indigenous house building still stand strong. This can be seen from the bamboo walls that are still standing and the protective roof is still attached tightly to protect the furniture inside. The lack of damage that occurred in Segenter was due to disaster mitigation that 
the community tried. The Segenter Society which is a cultural tourism area, in its life, uses structural and non-structural mitigation as disaster mitigation. This mitigation effort is a form of community and government contribution. The management of the tourism area is carried out by the government together with the community to become a tourist attraction that is repaired and improved in view of the devastating earthquake last year. These improvements range from infrastructure, security and comfort for tourists. In addition, efforts to form a disaster resilient community were also realized by the role of local community knowledge, facilities and the role of government.

The establishment of a disaster resilient community is strived to shape the character of a disaster prepared community. It provides an important role in disaster management because disaster risk can be minimized. This is relevant to the purpose of preparedness that seeks to anticipate disasters through organizing and through appropriate and efficient steps in a series of activities (BNPB, 2012). Anticipating disasters is a step to minimize the adverse effects of disasters that occur. Minimizing losses can be carried out with effective preventative measures, rehabilitation, and recovery to ensure effective and timely management and delivery of post-disaster assistance. With preparedness is expected to be able to avoid casualties, property losses, and changes in people's lives in the future (Sutton \& Tierney, 2006). Segenter Society shows local knowledge and the ability to think or behave openly to government policies.

The local knowledge of the community on the basics comes from the values of local wisdom they possess. The value of local wisdom is born from a society, passed down from generation to the next generation, and is preserved through habituation to form personality according to the norm. Local wisdom of the community which synergizes with the role of government in handling disasters makes the community more prepared to face disasters. The community has the provision to provide a role for more preparedness in facing changes that occur in their environment $(\mathrm{BNPB}, 2017)$ and the government plays a role in disaster management both in terms of education or infrastructure.

Non-structural mitigation in Segenter society is divided into several dimensions including knowledge, values, decision making mechanisms, and group solidarity. In the community's knowledge capacity, there is also the intervention of outsiders who provide disaster knowledge such as the Bayan Health Center. Whereas structural mitigation carried out in the Segenter Indigenous Village covers mechanical mitigation.

\section{Non-structural Mitigation}

\section{Knowledge}

The level of knowledge is one that must be developed and improved to gain insight in pre-disaster and post-disaster management in order to minimize the risk of disasters faced by companies in Turkey (Orhan, 2016). Knowledge is everything that humans know about a particular object which is a treasure of mental wealth obtained through the ratio and experience (Suriasumantri, 1996). The Segenter community knows that before a disaster occurs it is always marked by the sound of birds and strange animal behavior. This is relevant to the findings of Agung (2019) that animals would give cues when disasters will occur such as their strange behavior. In addition, the community also understands that the yellow moon marks a disaster in the near future. This community trust plays a role in shaping patterns of community behavior in protecting themselves and taking disaster mitigation actions. The signs came out from indigenous leaders (Pembekel) at night to the community through the kiai (Islamic leader) when they were togheter. In Segenter, the community respected and trusted the knowledge of the adat leader. This knowledge is used continuously by traditional leaders for generations in understanding natural signs. Traditional leaders' beliefs and knowledge are used to regulate people's behavior to be more vigilant and to protect their environment. 
The Segenter community also knows that the area is at risk of an earthquake and a volcanic eruption. In addition, the community has also received guidance, disaster education and health from the Bayan Community Health Center. The community also knows and understands how the BPBD appeals. BPBD delivers notification of forecasts on disaster to the public. The Segenter Society is open to the knowledge and participation of outsiders. The knowledge of Segenter's community as mitigation based on local wisdom, openness of the community, and education provided by the Bayan Health Center become the basis for disaster mitigation by the community. Public knowledge will contribute to readiness in dealing with disasters that occur in their environment. Regarding that community knowledge, it is proven that the knowledge of Society in Nepal encourages members of women's networks to advocate for earthquake-safe communities and implement risk reduction measures. This action has developed an understanding of the process scientifically and systematically, and increased their confidence with important new technical skills and new leadership roles in their communities to reduce the risk of earthquakes (Shrestha, 2019). Furthermore, disaster managers in Chile also utilize community and local knowledge, and validate political knowledge as an important element for efficient disaster management (Tironi \& Manríquez, 2019).

\section{Values}

Values are references and beliefs in determining choices (Mulyana, 2004). Values are also normative benchmarks that influence humans in determining their choices among alternative ways of acting. Choices in determining how people's lives work. Integrating local values, sharing everyday experiences, and sharing memories of risk becomes one of the strategies and guidelines for behavior that may be effective in encouraging citizens' disaster preparedness (Appleby et al., 2018). The Segenter Society is a Sasak people who have traditional values that have existed in their lives. The communities also have values related to disaster mitigation such as belief in supernatural beings, ancestral spirits, and guardians (spirits) all over the place. The watchman is believed to live by the community both in the home environment (epen bale) and the neighborhood where they live (epen gubug), even in rivers, forests, seas, land that is used as a place to grow crops, and in the construction of houses. This belief is in accordance with their beliefs about animism, which means believing in the existence of spirits or spirits in people's lives (Dhavamony, 1995). However, this belief does not make people worship spirits. They continue to believe in one God (Islam).

The community believes that everything has been created by God with their respective roles and has a life. Trust in God and His creatures provides a pattern for people's behavior in life. This makes the community always careful in acting and maintaining environmental sustainability. The community believes that God's relationship, the environment and humans must be emphasized in their balance to achieve harmony. This statement is reinforced by the theological approach theory about environmental ethics which states that human ethics towards the environment comes from religion with noble values (Amir, 2019). This shows how nature was actually created and human functions and the interactions that exist between nature and humans.

Religion teaches humans to maintain the balance of nature. All beings understand that there is a need for good relations between beings in life. In addition, there is a belief in the guardian creatures that live in the forest, within a certain radius around the forest are not allowed to build activities. This value makes the preservation of the forest environment run well. Society not only recognizes the existence of God and its power, but also recognizes that there are other forces and spirits inhabiting certain places that will affect human life directly or indirectly (Rayson et al., 2014). Both of these values play a role in regulating the behavior of the Segenter community in maintaining their behavior and can preserve their environment in residential areas, agricultural land, or forests. 


\section{Decision Making}

Natural disaster management aims to protect the community from disasters and their impacts. Disaster and Regional Disaster Management Agency (BPBD) is the executor of government administration in the field of disaster management and community protection against disasters, whether natural, non-natural or social disasters. In this case, disaster management efforts are carried out through the implementation of emergency response and recovery of the conditions of the people in the area.

Furthermore, officers make preparedness in overcoming natural disasters, such as appeals, emergency response, rehabilitation, and reconstruction. The announcement of the traditional leader (pembekel) to the community through the kiai to convey information on the way of life (Awik-awik Gubuk) and disaster is as a form of harmony between tradition and religion. This is supported by their belief in pembekel as a highly respected figure. The community is also very obedient to the attitude and advice of the kiai by manifesting it as a pattern of worship approach and introduction to human relations with God (Amalia, 2017).According to Indonesian Dictionary (Kamus Besar Bahasa Indonesia--KBBI) awik-awik is Traditional law in the form of regulations that are prepared and stipulated by community members regarding the rules of community life in the fields of religion, culture and socio-economics. Awik-awik in Segenter society includes the separation between residential land and farming land by hedges and prohibiting the use of forest land as built up land. This rule is an effort to maintain and preserve the community's environment, both on residential land, agricultural land, or forests.

The relationship between pembekel and kiai in the context of delivering information to the community as an effort to maintain good togetherness for tradition can continue for generations. This disaster information is related to how to maintain the continuity of life and signs of impending disaster. Community togetherness usually occurs on Islamic holidays and traditional events. The main event of the community gathering is that the community is expected to be able to conduct early detection of disaster events and their impact can be minimized through the announcement from Kiai or Pembekel.

\section{Group Solidarity}

Humans are social creatures who have social dependence to always live with others. As social beings, of course humans themselves need other humans in living their lives. That's where social relations will be born from interactions that go well. Various social groups consisting of families, professional organizations, regional organizations, and so on so that each member would interact with each other either in direct contact or indirectly. This process of solidarity is the most important for achieving a common goal.

The form of group solidarity occurs in the form of joint awareness by strengthening social networking networks that closely encourage the community to do business together such as mutual cooperation. The Segenter community has a strong mutual cooperation spirit. This is reflected by the farming ceremony. In addition to the ceremony, the spirit of mutual cooperation was also seen when other community members were affected physically, materially, and spiritually (Amalia, 2017). One community will help other community members. In this connection, a life of high solidarity makes relations between members of the community harmonious. Social solidarity in society is divided into two, as in the perspective of the strength of cooperation and the value of mutual cooperation in the community (Zahnow et al., 2019). Thus, the higher the value of mutual cooperation, the higher the social value they have. In addition, there is a tradition of community gatherings held every night, Islamic holidays, and at traditional events. This community gathering tradition reflects the solidarity of the community in establishing communication and the continuation of tradition for generations. This association also opens up local knowledge and discusses education from outside parties for the good of the Segenter community. 
Local knowledge is knowledge that is owned by the local community on their environment. Local knowledge is knowledge that already exists in people's lives that is positive in relation to nature and the environment, this is sourced from religious values, customs, ancestral advice or local culture (Rindrasih, et al., 2018). Acceptance of knowledge from outsiders is a public openness to new knowledge which is usually difficult for indigenous peoples. Therefore, the Segenter community belongs to an open society.

He refers to people who are open to information, ideas, theories, and research results that have more truth levels (Asriningpuri, 2018). The openness of indigenous peoples can be seen from the input provided by the Bayan Community Health Center and received a call for disaster forecasts from the BPBD. This knowledge is adjusted to the local knowledge of indigenous peoples. In this case, traditional leaders and religious leaders also play an important role in making decisions to receive information from outside the Segenter.

\section{Structural Mitigation}

Mitigation actions taken by the Segenter Indigenous Village community are not only non-structural mitigation, but also in the form of structural mitigation. Structural mitigation is an action to reduce the impact caused by physical disasters such as infrastructure development or infrastructure facilities (BNPB, 2008).

This mitigation can take the form of mechanical and vegetative, or a combination of both (Maulana et al., 2017; Wulan et al., 2016). Mechanical structural mitigation is usually chosen for communities around the beach by installing evacuation pathway signs, reverse flow signposts on the beach, seawall, and breakwater (Wulan et al., 2016).

The use of cube, groin, river stone, limestone, sand in sacks, and talud beach shelters is also a mechanical mitigation (Maulana et al., 2017). Mitigation efforts found in the Segenter community are putting up signs on the volcano disaster evacuation route. This is intended as information or direction for visitors and the community when a volcano erupts. Evacuation routes in disaster areas are important so that people do not panic when natural disasters occur (Delita, 2017). The evacuation route is one form of concern for disaster mitigation. In addition, the community also has a role in mechanical structural mitigation through its local skills such as building facilities for disaster preparedness independently. Local skills are a form of community ability as a result of adaptation and understanding of their lives. Community skills are supported by resources in the surrounding environment.

The Segenter community has the skills to make earthquake resistant houses as has been experienced by the Sade and Bayan indigenous people. In addition, the traditional houses of Kampung Naga, Garut, West Java also did not collapse during an earthquake (Salasah, 2018). Earthquake resistant houses have three principles such as simple and symmetrical floor plans, building materials must be as light as possible, and load-bearing construction systems that must be adequate include roof structures, walls, and foundations (Sahay, 2010). Home building materials in Segenter are made of bamboo, rattan, reeds, and wood. The community uses bamboo as the wall of their home. Endy Sugijono, a house made of bamboo does not collapse because when an earthquake happens, the bamboo building will also shake (Sugijono, 2009). The concept that exists in earthquake-resistant houses is a form of adaptation of the community to the environment. The earthquake resistant house became the center of attention of experts as a house that has a sustainable system.

According to Arief (2016) sustainable building is interpreted as an ecological house, where the concept provides the benefits of improving air quality in the building space and reducing environmental impacts, minimizing liquid waste and the effects of heating in space. The construction of houses that are united and made from natural materials is a solution in establishing good relations with nature. In addition, paying attention and being responsible to the environment becomes a commitment in achieving a better life. This is what was applied by the Segenter community in building their houses. Nature always has a role in their lives like other Lombok Sasak tribes that humans are equal to nature (Rayson et al., 2014). 
Table 1. Disaster Mitigation in Segenter community, North Lombok

\begin{tabular}{|c|c|l|}
\hline Group & Dimension & \multicolumn{1}{c|}{ Mitigations } \\
\hline \multirow{1}{*}{$\begin{array}{c}\text { Non- } \\
\text { Structural } \\
\text { Mitigation }\end{array}$} & Knowledge & $\begin{array}{l}\text { a.Understanding signs before a disaster such as the sound of birds and } \\
\text { the yellow moon } \\
\text { b. Understanding when disaster will occur in the near future such as } \\
\text { the red moon } \\
\text { c. Disaster education from the Bayan Health Center } \\
\text { d. Understanding that the area is prone to earthquakes and volcanoes } \\
\text { e.Understanding BPBD's call when delivering forecasts of forecasts } \\
\text { about disaster }\end{array}$ \\
\cline { 2 - 3 } & $\begin{array}{l}\text { Vecision } \\
\text { guardians (spirits) all over the place } \\
\text { b. The belief that there are guardians (spirits) that live in the forest } \\
\text { within a certain radius around the forest should not be used for } \\
\text { awakening activities }\end{array}$ \\
\cline { 2 - 4 } & $\begin{array}{l}\text { Making } \\
\text { through the Kiai to convey information on how to live (awik-awik } \\
\text { gubuk) and disaster }\end{array}$ \\
\cline { 2 - 4 } & $\begin{array}{l}\text { Group } \\
\text { Solidarity }\end{array}$ & $\begin{array}{l}\text { a.Strong mutual cooperation culture } \\
\text { b. The tradition of community gatherings every night } \\
\text { c. The tradition of gatherings during traditional events and Islamic holidays } \\
\text { d. Openness among fellow citizens in anticipating disaster }\end{array}$ \\
\hline $\begin{array}{l}\text { Structural } \\
\text { Mitigation }\end{array}$ & Mechanic & $\begin{array}{l}\text { a.Signs for evacuation routes } \\
\text { b. The skill to make earthquake resistant houses }\end{array}$ \\
\hline
\end{tabular}

\section{CONCLUSION}

One of the interesting cultural tourism in Indonesia is the Segenter traditional tourism. This tour is precisely located in North Lombok. It is located in the transition area of Mount Raung to the south and Carik Beach to the north. This position puts the Segenter at risk of disaster. The community seeks to minimize the impact of the disaster by carrying out structural and non-structural mitigation. Non-structural mitigation Segenter society involves dimensions of knowledge, values, decision-making mechanisms, and group solidarity. Non-structural mitigation is derived from local knowledge of the community as well as outside influences. Efforts to mitigate disasters originating from insiders, the community uses its local wisdom. Whereas external mitigation such as the education efforts provided by the Bayan Health Center on health and disaster. Meanwhile, structural mitigation carried out by the Segenter community is mechanical structural mitigation. This is sought by BPBD such as a volcano disaster evacuation route board. In addition, local skills possessed by local people also play a role in mechanical structural mitigation efforts such as the community's ability to make earthquake-resistant houses using natural resources in their environment.

\section{Acknowledgments}

Special thanks to Universitas Negeri Malang for financial support on this research.

\section{REFERENCES}

Amalia, A. R. (2017). Tradisi perkawinan merarik suku sasak di lombok: Studi kasus integrasi agama dengan budaya masyarakat tradisional (Thesis). UIN Syarif Hidayatullah, Jakarta.

Amir, S. A. (2019). Dasar Pendekatan Etika Lingkungan Hidup yang Wajib Dipahami. Retrieved July 10, 2019, from Sentral Sistem website: https://sentralsistem.com/news/detail/3-dasar-pendekatan-etikalingkungan-hidup-yang-wajib-dipahami.

Anggito, A., \& Setiawan, J. (2018). Metodologi Penelitian Kualitatif. Sukabumi: Jejak.

Appleby-Arnold, S., Brockdorff, N., Jakovljev, I., \& Zdravković, S. (2018). Applying cultural values to encourage disaster preparedness: Lessons from a low-hazard country. International Journal of Disaster Risk Reduction, 31, 37-44. https://doi.org/10.1016/j.ijdrr.2018.04.015. 
Arief, A. Z. (2016). Implementasi konsep ecohouse dan ecoliving pada arsitektur permukiman tradisional Sasak. Spectra, 27(XIV), 1-14.

Artiani, L. E. (2011). Dampak ekonomi makro bencana: Interaksi bencana dan pembangunan ekonomi nasional. Prosiding Seminar Nasional Informatika, 67-74. Yogyakarta: UPN.

Asriningpuri, H. (2018). Belajar dari kearifan lokal untuk bersikap tanggap bencana alam. LAKAR jurnal Arsitektur, $01(01)$, 39-48.

Bintoro, A. (2019, November 27). Menyoal Kemampuan Hewan Membaca Tanda Bencana Alam. CNN Indonesia. Retrieved from https://www.cnnindonesia.com/teknologi/20171127144946-199-258380/ menyoal-kemampuan-hewan-membaca-tanda-bencana-alam.

Delita, F. (2017). Community Based Mitigation (Case study of mount Sinabung eruption Karo Regency, North Sumatra Province). Sumatra Journal of Disaster, Geography and Geography Education, 1(2), $105-109$.

Dhavamony, M. (1995). Fenomenologi Agama. Yogyakarta: Kanisius.

Fitrah, M., \& Luthfiyah, L. (2017). Metodologi Penelitian: Penelitian Kualitatif, Tindakan Kelas, \& Studi Kasus. Sukabumi: Jejak.

Gumelar, G. (2018). BNPB Sebut Total Kerugian Gempa Lombok Capai Rp12 Triliun. CNN. Retrieved from https://www.cnnindonesia.com/ekonomi/20180910124912-532-329123/bnpb-sebut-total-kerugiangempa-lombok-capai-rp12-triliun.

Isa, M. (2016). Bencana alam: Berdampak positif atau negatif terhadap pertumbuhan ekonomi? University research colloquium, 147-156.

Maulana, E., Wulan, T. R., Wahyuningsih, D. S., \& Mahendra, W. W. Y. (2017). Strategi pengurangan risiko abrasi di pesisir Kabupaten Rembang, Jawa Tengah. MediaTor, 1O(2), 177-189.

Mulyana, R. (2004). Mengartikulasikan Pendidikan Nilai. Bandung: Alfabeta.

Oloruntoba, R., Sridharan, R., \& Davison, G. (2018). A proposed framework of key activities and processes in the preparedness and recovery phases of disaster management. Disasters, 42(3), 541-570. https:// doi.org/10.1111/disa.12268.

Orhan, E. (2016). Building community resilience: Business preparedness lessons in the case of Adapazarı, Turkey. Disasters, $4 O(1), 45-64$. https://doi.org/10.1111/disa.12132.

Permadi, L. A., Asmony, T., Widiana, H., \& Hilmiati, H. (2018). Identifikasi potensi desa wisata di Kecamatan Jerowaru, Kabupaten Lombok Timur. Jurnal Pariwisata Terapan, 2(1), 33. https://doi.org/10.22146/jpt.35380

Rayson, Y., Ridjal, A. M., \& Suryasari, N. (2014). Peran Kosmologi terhadap pembentukan pola ruang permukiman. Jurnal Mahasiswa Arsitektur, 2(2), 8.

Rindrasih, E., Hartmann, T., Witte, P., Spit, T., \& Zoomers, A. (2018). Travelling without a helmet: Tourists' vulnerabilities and responses to disasters in Indonesia. Disasters, 42(4), 782-803. https://doi.org/ $10.1111 /$ disa.12281.

Sahay, N. S. (2010). Penerapan bentuk desain rumah tahan gempa. Jurnal Perspektif Arsitektur, 5(1), $33-42$.

Salasah, R. (2018). Dibalik Crita Bangunan Adat Kampung Naga, Rumah Tradisional Sunda Tahan Gempa. Idea. Retrieved from https://idea.grid.id/read/o9913719/dibalik-cerita-bangunan-adat-kampung-nagarumah-tradisional-sunda-tahan-gempa?page=all.

Sugijono, E. (2009). Tahan Gempa, Rumah Bambu Bisa Bertahan Hingga 20 Tahun. Detik News.

Suriasumantri, J. (1996). Filsafat Ilmu: Sebuah Pengantar popular. Jakarta: Pustaka Sinar Harapan.

Sutton, J., \& Tierney, K. (2006). Disaster preparedness: Concepts, guidance, and research. Colorado: University of Colorado.

Thene, J. (2016). Mitigasi Bencana Gempa Bumi Berbasis Kearifan Lokal Masyarakat Rote Kabupaten Rote Ndao Provinsi Nusa Tenggara Timur. Jurnal Teori dan Praksis Pembelajaran IPS, 1(2), $102-106$. https://doi.org/10.17977/um022v1i22016p102.

Tironi, M., \& Manríquez, T. (2019). Lateral knowledge: Shifting expertise for disaster management in Chile. Disasters, 43(2), 372-389. https://doi.org/10.1111/disa.12313.

Wulan, T. R., Ambarwulan, W., Wahyuningsih, D. S., Maulana, E., Raharjo, T., Ibrahim, F. \& Megawati, E. I. (2016). Mitigasi bencana berbasis potensi wisata: Studi kasus pantai pandawa, Desa Kutuh, Kecamatan Kutu Selatan, Kabupaten Badung, Provinsi Bali. Prosiding Nasional Kelautan 2016, 261-266. Madura: Universitas Trunojoyo.

Yusuf, M. (2017). Metode Penelitian: Kuantitatif, Kualitatif, \& Penelitian Gabungan. Jakarta: Kencana.

Zahnow, R., Wickes, R., Taylor, M., \& Corcoran, J. (2019). Community social capital and individual functioning in the post-disaster context. Disasters, 43(2), 261-288. https://doi.org/10.1111/disa.12317.

*** BMKG, T. (2019). Katalog Gempa Bumi BMKG. Jakarta: BMKG.

*** BNPB. Peraturan Kepala BNPB. , 4 Pedoman penyusunan rencana penanggulangan bencana $\S(2008)$.

*** BNPB. Peraturan Kepala BNPB. , 1 Pedoman umum desa/kelurahan tangguh bencana $§(2012)$.

*** BNPB, T. (2017). Membangun kesadaran, kewaspadaan, dan kesiapsiagaan dalam menghadapi bencana (II). Jakarta: BNPB.

*** BPS Lombok Utara, T. (2017). Kabupaten Lombok Utara dalam data. Lombok Utara: BPS Lombok Utara.

Submitted:

19.08.2019
Revised:

09.12.2019
Accepted and published online 10.12.2019 